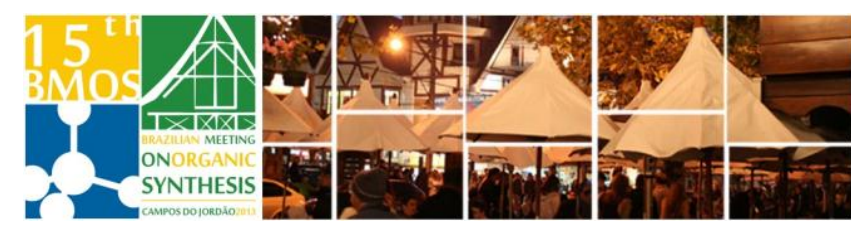

\title{
Synthesis and antioxidant activity of nitroaryl-1,2,3-triazoles
}

\author{
Wagner O. Valença, * Pollyanna L. F. da Costa, Jucleiton J. R. de Freitas, Tânia Maria \\ S. da Silva, Ronaldo N. de Oliveira *

\begin{abstract}
Departamento de Ciências Moleculares, Universidade Federal Rural de Pernambuco, Recife, PE, Brazil
*E-mails: wagnerufrpe@yahoo.com.br; ronaldonoliveira@dcm.ufrpe.br
\end{abstract}

Keywords: 1,2,3-triazole, cycloaddition, antioxidant activity

\section{INTRODUCTION}

1,2,3-Triazole derivatives are known to exhibit a range of biological activities such as, antiinflamatory, antileishmanial and anti-T. cruzi. ${ }^{1-3}$ The nitroaryls and nitroheterocycles are considered to be medicinally a valuable group of compounds, broadly redox properties of nitroaromatic compounds are associated to biological activities. ${ }^{4}$ In our antioxidative screening study of nitroaryl-1,2,3triazoles using free radical scavenging activity of $\mathrm{DPPH}$ and ABTS, we report here some active compounds.

\section{RESULTS AND DISCUSSION}

We performed the synthesis of bis-aryl-1,2,3triazoles 17-22 and a variety of functional groups 2331 linked via 1,3-dipolar cycloaddition reaction (1,3DCR). The reaction between $1 \mathrm{mmol}$ of nitroarylazide 1 and $1.5 \mathrm{mmol}$ of terminal alkynes $\underline{\mathbf{2 - 1 6}}$ was carried out in the presence of $10 \mathrm{~mol} \%$ Cul, using $\mathrm{CH}_{3} \mathrm{CN}$ as solvent and stirring at room temperature under argon atmosphere for $24 \mathrm{~h} .{ }^{5}$ The compounds were obtained in moderate to good yields of 5094\% (Scheme).

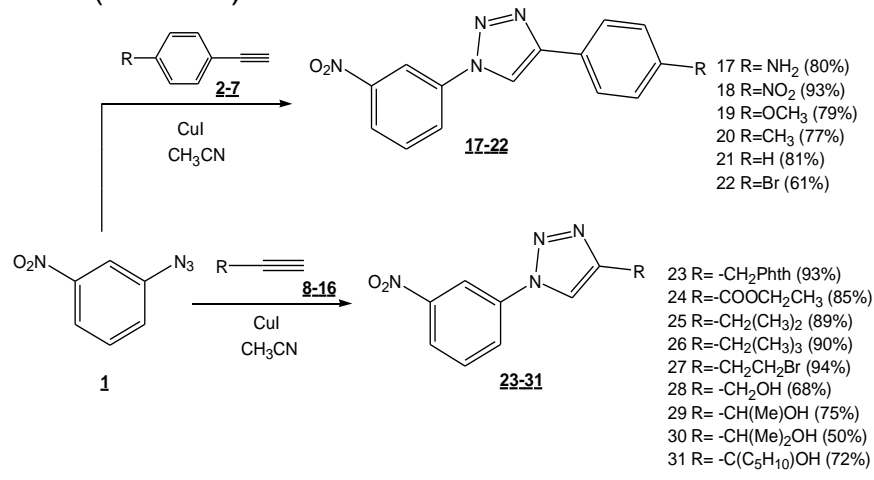

Scheme. Synthesis of the nitroaryl-1H-1,2,3-triazole 17-31

All the compounds have been tested their scavenging activity (\%SA) and their antioxidant concentration required to inhibit $50 \%$ of the radicals $\left(\mathrm{EC}_{50}\right){ }^{6}$ Only the compounds containing functional groups that were susceptible to oxidation, such as hydroxyl 28-29 and amine 17, showed the best antioxidant activities (Table). These results may be rationalized because the 1,2,3-triazole group is known as stable, and now we have described their stability under scavenging conditions.

Table. The best results for antioxidant activities of nitroaryl-1H-1,2,3-triazoles.

\begin{tabular}{|c|c|c|}
\hline \multirow{2}{*}{ Compounds } & \multicolumn{2}{|c|}{$\mathrm{EC}_{50}(\mu \mathrm{g} / \mathrm{mL})^{\mathrm{a}}$} \\
\hline & DPPH $^{\mathrm{b}}$ & ABTS $^{\circ}$ \\
\hline 17 & $7.79 \pm 1.68$ & $13.42 \pm 0.97$ \\
\hline 28 & $49.75 \pm 1.37$ & $32.98 \pm 0.39$ \\
\hline 29 & $47.97 \pm 5.42$ & $22.23 \pm 0.07$ \\
\hline Ascorbic acid & $1.67 \pm 0.02$ & - \\
\hline TROLOX & - & $3.86 \pm 0.04$ \\
\hline
\end{tabular}

\section{CONCLUSION}

We have synthesized a series of nitroaryl-1 $\mathrm{H}-1,2,3-$ triazoles 17-31 in moderate to good yields. Only the compounds $\underline{17}, \underline{28}$ and $\underline{29}$ presented satisfactory results as an antioxidant. These three compounds have been found to be a lead antioxidant agent for further study.

\section{ACKNOWLEDGEMENTS}

The authors are grateful to CNPq, FACEPEPRONEM for financial support and CAPES for providing a fellowship to one of us (W.O.V.). Our thanks are also due to Analytical Centers CENAPESQ-UFRPE and DQF-UFPE.

\section{REFERENCES}

${ }^{1}$ Kumar, S.S.; Kavitha, H. P.; Mini-Rev. Org. Chem. 2013, 10, 40; Agalave, S. G.; Maujan, S. R.; Pore, V. S.; Chem. Asian J. 2011, 6, 2696.

${ }^{2}$ Assis, S. P. O.; da Silva, M. T.; de Oliveira, R. N.; Lima, V. L. M.; The Scientific World Journal 2012, ID 925925, DOI: 10.1100/2012/925925.

${ }^{3}$ Guimarães, T. T.; Pinto, M. C. F. R.; Lanza, J. S.; Melo, M. N.; Monte-Neto, R. L.; de Melo, I. M. M.; Diogo, E. B. T.; Ferreira, V. F.; Camara, C. A.; Valença, W. O.; de Oliveira, R. N.; Frézard, F.; da Silva Jr, E. N.; Eur. J. Med. Chem. 2013, 63, 523.

${ }^{4}$ Wardman, P.; Environ. Health Perspect. 1985, 64, 309.

${ }^{5}$ Valença, W. O.; de Freitas, J. J. R.; de Oliveira, R. N.; Orbital Elec. J. Chem. 2012, 4 (Suppl. 1), 31.

${ }^{6}$ Souza, S.A.; Camara, C. A.; da Silva, E. M. S.; da Silva, T. M. S.; Evidence-Based Complementary and Alternative Medicine 2013, ID 801383, DOI: http://dx.doi.org/10.1155/2013/801383. 